\section{Dr. Claudia I. Mora}

\section{IUGS Councillor (2018-2022)}

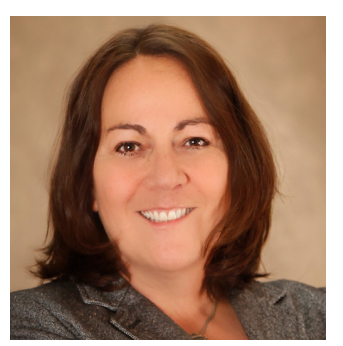

I was introduced to geology by my older sister, who needed a field assistant for a day of geological mapping. Although I spent more time that day chasing lizards than looking at rocks, it struck me that the ability to wander mountains and call it work had distinct possibilities. That was the encouragement I needed to enroll in Physical Geology in my first year of college and I never looked back! My sister and I both became geologists and sometimes we still wander mountains together. I still like to give chase to lizards, but they seem to have evolved great speed. I am so happy with the geoscience career that she helped me find. I thrive on experimental science and being constrained by data. I love the process of science and that the complexity of geological systems demands the full breadth of basic science, observations across many scales, and collaboration with experts in many fields.

My academic studies moved me around the U.S. As an undergraduate at the University of New Mexico (B.S. 1980), I found work with Dr. Doug Brookins on the geochemistry of uranium ore deposits and associated clay minerals. I continued my studies at Rice University, where I completed a thesis on the thermobarometry of the granulitefacies Oaxacan Complex in southern Mexico (M.S. 1983), working with Dr. John Valley. I followed Dr. Valley to the University of WisconsinMadison for my Ph.D. studies on metamorphic fluid-rock interaction in Proterozoic scapolite-bearing metasediments surrounding the very unusual Boehls Butte anorthosite (Ph.D. 1988).

My academic career began in 1989, when I joined the faculty at the Department of Earth and Planetary Sciences, University of Tennessee-Knoxville, the first woman professor in the department. There I built a stable isotope laboratory and established a productive, wideranging research program that evolved from petrology to emphasize stable isotope geochemistry, and I developed a keen interest in the isotope proxy record of climate and environment preserved in terrestrial archives (modern soils, paleosols, tree rings, lake sediments). My research required strongly collaborative, multidisciplinary teams: I worked closely with a sedimentologist and soil scientist to understand chemical and stable isotope proxies for paleoclimate and atmospheric $\mathrm{pCO}_{2}$ preserved in paleosols, and with a dendrochronologist to develop high-resolution isotope proxies for extreme events (tropical cyclones, drought). I am a little proud of the fact that my three most-cited papers are in very different areas of geoscience: soil/paleosol science (Mora et al, 1996, Science), isotope dendroclimatology (Miller et al. 2006, PNAS) and metamorphic petrology (Mora and Valley, 1989, American Mineralogist)! From 2002-2007, I was named Carden Professor and served as Head of the Department at UTK. Through that position, I discovered how much I enjoy management of the science enterprise: enabling colleagues to thrive in their research, helping to identify and support strategic research efforts, to build the necessary collaborations and infrastructure, and to address the scientific needs of our larger institution and society.
In 2007, I began a second career at Los Alamos National Laboratory (LANL). Walking away from a successful academic career at the age of 49 to support my spouse in his own special career opportunity was difficult. There are many differences in the missions and research environment between academia and a national security laboratory and I was challenged to understand and adapt my skills to a new set of research questions. But, it led me to new and stimulating opportunities at the most iconic of the U.S. National Laboratories. I built (another!) stable isotope laboratory and sought new research directions. From 2010-2017, I was Group Leader for a large and diverse group of experimental geochemists and ecologists in the LANL Earth and Environmental Sciences Division. My academic research skills found use in the national security environment of LANL for studies ranging from greenhouse gas detection and attribution, climate change impacts on permafrost, and biofuel coprocessing, to nuclear and chemical weapons forensics. There is so much you can do with scientific curiosity, good training, clever colleagues, and a nice mass spectrometer! I moved in 2017 to become Deputy Division Leader for LANL's Chemistry Division. There are a surprising number of geochemists in our Division. It turns out that geological studies, which typically involve complex, open systems, and constraining a solution despite limited and incomplete data, is the perfect training ground for technical nuclear forensics or radiochemical debris analysis. And so, forty years after my undergraduate work, I am in the business of studying uranium again - proof that the earth is round!

Throughout my career, I have enjoyed contributing to the professional geological community. I have had the privilege to serve on the Editorial Board for Geology, and as Councilor and President of the Geological Society of America, a society that takes special pride in its sponsorship of student research grants and geological field research. I have participated in many strategic workshops, research and fellowship panels, and as a member of the Geoscience Advisory Board for the National Science Foundation. I have been a member of the National Research Council Board on Earth Sciences and Resources, and both the U.S. National Committees for Soil Sciences and Geological Sciences. It was as a member of the USNC-GS that I attended the $35^{\text {th }}$ IGC in Capetown, South Africa and began to better understand the important work of the IUGS and its Commissions, Joint Programs and Task Groups. I have been impressed by the intellect, hard work and the diverse, global face of the geoscientists who are the heart and soul of so many IUGS efforts. And I am extremely honored now to serve as IUGS Councilor, and hope to bring as much dedication and enthusiasm to the job as so many of you do in your own IUGS efforts.

I am supported in all my endeavors by my husband, Pete Maggiore. When we are not juggling our responsibilities at work and the needs of 5 children in various stages of launching into adulthood, we like to spend time in Taos, New Mexico. We relish the ancient beauty of Taos Pueblo, the plentiful live music and hours of peaceful reading in a small adobe casita, tucked in the shade of a cottonwood, between the deep Rio Grande Gorge and the rugged Sangre de Cristo Mountains. 